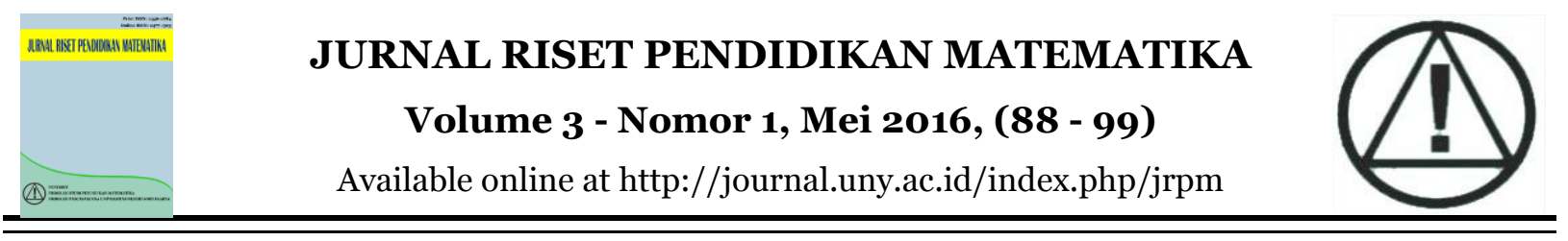

\title{
PENGEMBANGAN MULTIMEDIA PEMBELAJARAN TRIGONOMETRI MENGGUNAKAN ADOBE FLASH CS3 UNTUK SISWA SMA
}

\author{
Nanang Khuzaini ${ }^{1}{ }^{*}$, Rusgianto Heri Santosa ${ }^{2}$ \\ ${ }^{1}$ Jurusan Pendidikan Matematika, Universitas Mercu Buana Yogyakarta, Jalan Wates Km 10, Daerah \\ Istimewa Yogyakarta 55753, Indonesia \\ ${ }^{2}$ Jurusan Pendidikan Matematika, Universitas Negeri Yogyakarta. Jalan Colombo No. 1, \\ Karangmalang, Yogyakarta 55281, Indonesia \\ * Korespondensi Penulis. Email: nanangkhuzaini@gmail.com, Telp: +628562563729 \\ Received: 15 ${ }^{\text {th }}$ June 2016; Revised: $7^{\text {th }}$ September 2016; Accepted: $8^{\text {th }}$ September 2016
}

\begin{abstract}
Abstrak
Penelitian ini bertujuan untuk menghasilkan multimedia pembelajaran trigonometri menggunakan ADOBE FLASH CS3 untuk pembelajaran matematika siswa SMA kelas X semester II dan mengetahui kelayakan produk multimedia dari aspek kevalidan, kepraktisan, dan keefektifan untuk pembelajaran matematika di SMA Kelas X Semester II. Penelitian ini merupakan penelitian pengembangan multimedia pembelajaran matematika menggunakan model pengembangan Borg dan Gall yang dilaksanakan melalui tiga tahapan yaitu: pertama, pendahuluan yaitu studi pustaka dan studi lapangan; kedua, pengembangan yaitu perencanaan dan pengembangan produk awal; dan ketiga, uji lapangan yaitu uji pengembangan terbatas, uji coba kelompok kecil, dan uji coba lapangan. Hasil penelitian menunjukkan bahwa multimedia yang dihasilkan dalam pengembangan multimedia pembelajaran matematika trigonometri adalah baik dilihat dari aspek kevalidan, kepraktisan, dan keefektifan suatu multimedia pembelajaran.
\end{abstract}

Kata Kunci: pengembangan multimedia pembelajaran matematika, adobe flas CS3, trigonometri

\section{DEVELOPING AN TRIGONOMETRY MULTIMEDIA INSTRUCTION USING ADOBE FLASH CS3 FOR SMA STUDENT}

\begin{abstract}
This research aims to develop trigonometry multimedia intruction using ADOBE FLASH CS3 for the teaching of mathematics on the semester II class X of SMA and reveal the feasibility of the product in the aspects of validity, practicality and effectiveness aspec. This research is development research use Borg and Gall development models, conducted through three phases: first, introduction that included the study of literature and field studies; second, development that included the planning and development of the initial product; trird, field testing which included a limited development testing, a small group testing, and field trials. The result of research indicating that resulted in the development of multimedia learning multimedia math Trigonometry is good seen from the aspect of validity, practicality, and effectiveness of a multimedia learning.
\end{abstract}

Keywords: development mathematics multimedia instruction, adobe flash CS3, trigonometry

How to Cite: Khuzaini, N., \& Santosa, R. (2016). Pengembangan multimedia pembelajaran trigonometri menggunakan adobe flash CS3 untuk siswa SMA. Jurnal Riset Pendidikan Matematika, 3(1), 88-99. doi:http://dx.doi.org/10.21831/jrpm.v3i1.9681

Permalink/ DOI: http://dx.doi.org/10.21831/jrpm.v3i1.9681 


\section{Jurnal Riset Pendidikan Matematika, 3 (1), Mei 2016 - 89}

Nanang Khuzaini, Rusgianto Heri Santosa

\section{PENDAHULUAN}

Matematika merupakan ilmu universal yang mendasari perkembangan teknologi modern, mempunyai peran penting dalam berbagai disiplin dan memajukan daya pikir manusia (Peraturan Pemerintah Nomor 22, 2006). Penguasaan matematika sejak dini sangat diperlukan dalam mempersiapkan generasi penerus bangsa yang kreatif, inovatif, dan memiliki daya saing tinggi. Oleh karena itu, tingkat penguasaan matematika dapat dijadikan sebagai tolak ukur kemajuan suatu bangsa.

Matematika merupakan salah satu mata pelajaran yang sulit dan menyebabkan siswa mengalami kesulitan untuk memahami materi pelajaran matematika yang abstrak (Muijs \& Reynalds, 2005, p.218). Menurut Sunnetha (Ayda \& Widjajanti, 2014, p.217) pelajaran matematika merupakan salah satu mata pelajaran yang memiliki manfaat besar dalam kehidupan. Matematika memberikan kesempatan kepada siswa untuk melatih mental mereka dan akan berpengaruh terhadap perkembangan intelektual mereka. Melalui pelajaran matematika siswa akan mampu belajar untuk memperoleh pengetahuan secara sistematis. Kesulitan siswa mempelajari matematika juga disebabkan oleh sifatnya yang abstrak dan membutuhkan kemampuan berpikir logis serta terurut (Sousa, 2008, p. 2). Jadi, tidak salah jika sebagian besar siswa tidak cukup tertarik dan yakin mampu mempelajari matematika dengan baik. Menurut Van den Heuvel-Panhuizen (2000, p.19), bila anak belajar matematika terpisah dari pengalaman mereka sehari-hari maka anak akan cepat lupa dan tidak dapat mengaplikasikan matematika.

Permendiknas Nomor 41 Tahun 2007 (BSNP, 2007, p.6) menerangkan bahwa guru merupakan salah salah satu bagian penting yang mengantarkan keberhasilan dalam pendidikan. Menurut Mulyasa (2013, p.13), guru mempunyai peran sentral dalam setiap pembelajaran yaitu sebagai perencana, pelaksana, dan evaluator. Untuk melaksanakan peran tersebut, guru harus mampu memberikan keteladanan, membangun kemauan, mengembangkan potensi, dan kreativitas siswa. Kemampuan membangun dan mengembangkan potensi siswa dapat dilakukan dengan memfasilitasi dan memberikan arahan kepada siswa. Peran guru sebagai fasilitator adalah memberikan kesempatan kepada siswa untuk berkembang sesuai dengan potensinya.
Trianto (2009, pp.5-7) menyatakan bahwa terdapat kondisi yang berbeda jika dilapangan, proses pembelajaran sering didominasi oleh pembelajaran konvensional. Pembelajaran konvensional lebih disukai guru dikarenakan tidak banyak memerlukan alat dan bahan praktik, guru cukup menjelaskan konsep-konsep yang terdapat pada buku ajar atau referensi lain. Pembelajaran yang berpusat pada guru ini menjadikan siswa hanya menghapal konsep-konsep yang diberikan guru. Hal ini menjadikan keputusasaan, kebosanan, dan kurang maksimalnya perkembangan potensi siswa.

Dalam perkembangannya, inovasi teknologi sudah menjadi bagian tak terpisahkan dengan dunia pendidikan. Adanya dukungan teknologi dibidang pendidikan, membuat guru terbantu dalam upaya meningkatkan kualitas pembelajaran. Dalam Pembelajaran, guru yang menggunakan teknologi dapat mempercepat, mempermudah, dan memperlancar proses perencanaan, pelaksanaan, dan evaluasi dalam pembelajaran. Teknologi, utamanya multimedia mempunyai peranan penting dalam proses pembelajaran. Banyak orang percaya bahwa multimedia dapat membawa situasi belajar menjadi menyenangkan, kreatif, dan tidak membosankan. Peran teknologi dalam pendidikan dapat diterapkan dalam pembelajaran, penerapan teknologi ini sangat membantu proses pembelajaran dengan suatu ilustrasi yang dapat mempermudah siswa untuk mempelajari suatu materi pelajaran dalam matematika.

Salah satu alternatif yang dapat membantu siswa untuk melakukan banyak eksplorasi dalam waktu yang terbatas adalah dengan menggunakan bantuan komputer dengan berbagai software yang relevan. Beberapa software sangat ideal untuk dimanfaatkan dalam pembelajaran konsep-konsep yang menuntut ketelitian tinggi, konsep atau prinsip yang repetitif, penyelesaiaan grafik secara tepat, cepat dan akurat. Media pembelajaran berbasis komputer yang mutakhir meliputi text, graphic, audio, dan video yang dibuat, dikemas, disajikan, dan dimanfaatkan secara interaktif melalui komputer. Media pembelajaran matematika yang demikian disebut media pembelajaran matematika berbasis multimedia interaktif.

Hasil observasi dan wawancara terhadap 10 guru matematika di SMA/MA di kabupaten Bantul diperoleh fakta bahwa sebagian besar sekolah yaitu 7 dari 10 sekolah telah memiliki laboratorium komputer yang cukup memadai, tetapi fakta lain menunjukkan bahwa baru satu 
guru yang memanfaatkan laboratorium komputer untuk pembelajaran matematika. Mereka menganggap bahwa pembelajaran matematika cukup di kelas saja, sedangkan untuk penggunaan komputer di laboratorium hanya untuk pelajaran pengenalan komputer atau pelajaran Teknologi Informasi Komputer (TIK) saja.

Pada sisi lain, sebenarnya anak-anak setingkat SMA/MA telah banyak menguasai dan mengetahui banyak manfaat yang dieproleh lewat komputer internet. Mereka memperoleh pelajaran Teknologi Informasi dan Komunikasi (TIK) dan ekstrakurikuler komputer pada tingkat SMP/MTs, sehingga pelaksanaan pembelajaran matematika menggunakan media komputer bukanlah sesuatu yang asing bagi siswa. Hal ini sebenarnya merupakan peluang bagi guru untuk mengembangkan pembelajaran matematika dengan menggunakan media komputer.

Timbulnya pengaruh yang baik terhadap aktivitas siswa dan prestasi belajar siswa dalam setiap kegiatan pembelajaran merupakan tolak ukur berpikir bahwa proses pembelajaran telah dilaksanakan dengan baik. Oleh karena itu, penggunaan multimedia pembelajaran matematika diperlukan dalam pembelajaran matematika agar siswa mempunyai pengalaman belajar yang lebih menarik.

\section{Multimedia Pembelajaran}

Menurut Vaughan (2006, p.3), multimedia diartikan sebagai "Multimedia is any combination of text, graphic art, sound, animation, and video delivered to you by computer or other electronic mean"s. Multimedia merupakan gabungan teks (tulis), grafis (program cara penyampaian informasi), animasi, audio (dialog, cerita, efek suara), images (gambar dan penarik visual) dan video yang bergerak. Melalui gabungan media-media ini pengalaman belajar menjadi sesuatu yang interaktif yang mencerminkan suatu pangalaman dalam kehidupan sehari-hari.

Menurut Roblyer \& Doering (2003, p.172), bahwa "multimedia means multiple media or bination of media. Media can be still photogaphs, sound, motion video, and animatiom". Menurut Hackbarth (1996, p.129) "multimedia is suggested as meaning the use of multiple media formats for the presentation of information, including texts, still or animated graphics, movie segments, video, and audio informations". Pendapat ini mengatakan bahwa multimedia bisa diartikan sebagai penggunaan beberapa format media untuk menyampaikan informasi, termasuk didalamnya teks, gambar diam atau bergerak, film, video, dan audio.

Sejalan dengan Neo \& Neo (Gyongyver, 2001,p.1) menyatakan bahwa multimedia is the combination of various digital media types (e.g. images, sound, video, text) they compile an integrated multi-sensory interactive application to present the information to an audience. Selain itu multimedia pembelajaran menurut Munadi (2008, p.148) adalah media yang mampu melibatkan banyak indera dan organ tubuh selama proses pembelajaran berlangsung. Jadi, multimedia merupakan kumpulan atau kombinasi dari berbagai media berupa gambar, suara, gerak video, animasi, dan/atau teks yang bertujuan untuk mengkomunikasikan informasi.

Arsyad (2006, p.6) mengklasifikasikan pengertian media kedalam dua hal, yaitu pengertian fisik dan nonfisik. Sesuatu benda yang dapat dilihat, didengar, atau diraba dengan panca indera disebut pengertian fisik, sedangkan pengertian nonfisik yaitu kandungan pesan yang terdapat dalam perangkat keras yang merupakan isi yang ingin disampaikan kepada siswa. Media pembelajaran yang baik harus memenuhi beberapa syarat, yaitu media pembelajaran harus meningkatkan motivasi pembelajar, penggunaan media mempunyai tujuan memberikan motivasi kepada pem-belajar, dan media juga harus merangsang pembelajar mengingat apa yang sudah dipelajari selain memberikan rangsangan belajar baru.

Dari beberapa pendapat mengenai multimedia tersebut dapat disimpulkan bahwa multimedia adalah gabungan dari teks, gambar, seni grafik, animasi, suara, dan video yang berada dalam suatu kontrol program komputer dengan alat bantu (tool) dan koneksi (link) sehingga pengguna dapat bernavigasi, berinteraksi, berkarya dan berkomunikasi, sehingga komunikasi yang dihasilkan adalah komunikasi yang bernilai tinggi.

Pembelajaran, seperti telah diuraikan adalah suatu kegiatan kondusif yang sengaja direncanakan, dilakukan, dan dievaluasi oleh seorang guru untuk menciptakan suatu lingkungan yang memungkinkan siswa untuk belajar, dalam hal ini guru sebagai fasilitator. Maka dapat disimpulkan bahwa multimedia pembelajaran adalah gabungan dari teks, gambar, seni grafik, animasi, suara, dan video yang berada dalam suatu kontrol program komputer dengan alat bantu (tool) dan koneksi (link) untuk menciptakan suasana yang kondusif dalam suatu kegiatan yang sengaja dirancang, diterapkan, dan dieva- 


\section{Jurnal Riset Pendidikan Matematika, 3 (1), Mei 2016 - 91}

Nanang Khuzaini, Rusgianto Heri Santosa

luasi oleh seorang guru dengan tujuan menciptakan suatu kegiatan belajar bagi siswa.

\section{Manfaat Multimedia Pembelajaran}

Agnew, Kellerman \& Meyer (1996, p.155) menyatakan bahwa: "the experience indicates that young children can benefit from creating multimedia projects that include texts, graphics, images, audio, and video particurarly in the from animation". Pernyataan tersebut mengandung makna bahwa siswa bisa mendapat manfaat dan proyek multimedia yang memuat teks, grafik, gambar, audio, dan video khususnya animasi.

Pemanfaatan media pembelajaran juga tidak lepas dari fungsi media pembelajaran tersebut. Arsyad (2006, p.21) menyatakan bahwa media berfungsi untuk tujuan instruksi di mana informasi yang terdapat dalam media itu harus melibatkan siswa dalam benak atau mental maupun bentuk aktivitas yang nyata sehingga pembelajaran dapat terjadi. Dengan demikian media dapat berfungsi untuk mempertinggi daya serap dan retensi anak terhadap materi pembelajaran.

Alessi \& Trollip (2001, p.5) menyampaikan bahwa "hundreds of research studies have been conducted to prove that using computers to teach is better than using books, teachers, films, or other more traditional methods". Penelitianpenelitian tentang pendidikan telah membuktikan bahwa menggunakan komputer untuk mengajar lebih baik dari menggunakan buku, guru, film atau metode tradisional lainnya. Lebih lanjut Alessi \& Trollip (2001, p.40) menyebutkan bahwa "educators should use a variety of multimedia materials and approachly, and thus provide flexible learning environments meeting the needs of the greatest number of their learner". Jadi, dengan bantuan komputer pendidik/ guru dapat menyediakan lingkungan belajar yang fleksibel untuk jumlah siswa yang lebih banyak.

Borovcnik \& Kapadia (2009, p.116) menyampaikan bahwa "by using such media they describe learning steps in proportional thinking, right from the beginning in connection to probabilities". Dengan menggunakan media mereka (dalam hal ini guru) menjelaskan tahapan belajar dengan pemikiran yang proporsional, dimulai dari koneksi hingga kemungkinankemungkinan. Media sebagai sumber belajar merupakan komponen dari sistem instruksional disamping pesan, orang, teknik, latar dan peralatan. Pengertian media ini masih sering dikacaukan dengan peralatan. Dengan masuknya berbagai pengaruh dalam khazanah pendidikan, media dalam perkembangannya tampil dalam berbagai jenis dan format masing-masing dengan ciri-ciri dan kemampuannya sendiri.

Kemp \& Dayton (1985, pp.3-4) mengemukakan hasil penelitian yang menunjukkan dampak positif penggunaan media dalam pembelajaran, yaitu: (1) The delivery of instruction can be more standardized; (2) the instruction can be more interesting; (3) learning becomes more interactive trough applying accepted learning theory; (4) the length of time required for instruction can be reduced; (5) the quality of learning can be improved; (6) the instruction can be provided when and where desired and necessery; (7) the positive attitude of student toward what they are learning and they are learning process itself can be enhanced; (8) the role of the instructor can be appreclably changed in the positive directions.

Dapat dijelaskan bahwa peranan media dalam proses pembelajaran adalah: (1) penyampaian pelajaran menjadi lebih standar, (2) pembelajaran bisa lebih menarik, (3) pembelaran menjadi lebih interaktif, (4) lama waktu pembelajaran yang diperlukan dapat dipersingkat (efisien), (5) kualitas hasil belajar dapat ditingkatkan, (6) pembelajaran dapat diberikan kapan dan di mana saja, terutama jika media pembelajaran dirancang untuk peng-gunaan secara individu (fleksibel), (7) sikap positif siswa terhadap apa yang mereka pelajari dan terhadap proses belajar dapat ditingkatkan (bermakna dan menyenangkan), (8) peran guru dapat berubah ke arah yang lebih positif; beban guru untuk penjelasan yang berulang-ulang mengenai isi pelajaran dapat dikurangi atau bahkan dapat dihilangkan sehingga ia dapat memusatkan perhatian kepada aspek penting lain dalam proses belajar mengajar, misalnya sebagai konsultan atau penasihat siswa.

Sementara menurut (Arsyad, 2006, p.19), media pembelajaran dapat memenuhi tiga fungsi utama, yaitu (1) memotivasi minat atau tindakan, (2) menyajikan informasi, dan (3) memberi instruksi di mana informasi yang terdapat dalam media harus melibatkan siswa baik dalam benak atau mental maupun dalam bentuk aktivitas yang nyata sehingga pembelajaran dapat terjadi.

Menurut Newby, Stepich, Lehman, \& Russell (1996, p.108) media pembelajaran bagi guru dan siswa mempunyai beberapa kelebihan, diantaranya yaitu: better learning and retention, addresses different learning, effectiveness 


\section{Jurnal Riset Pendidikan Matematika, 3 (1), Mei 2016 - 92}

Nanang Khuzaini, Rusgianto Heri Santosa

accros learning domain, realism, motivation, interactivity, individualization, consistensi, learner control. Dari pernyataan tersebut dapat diartikan beberapa kelebihan pembelajaran menggunakan media diantaranya yaitu pembelajaran menjadi lebih baik, memberikan pengalaman belajar yang berbeda, lebih efektif dalam domain belajar, realistis, memotivasi dalam belajar, interaktif, belajar lebih mandiri, konsisten, serta belajar lebih terkontrol.

Dalam bidang pendidikan, penggunaan teknologi berbantuan komputer merupakan cara untuk menyampaikan materi dengan menggunakan sumber-sumber yang berbasis mikro komputer, dimana informasi atau materi yang disimpan dalam bentuk digital, dan penggunaan teknologi ini selalu terkait dengan penggunaan layar kaca untuk menyampaikan informasi atau materi kepada siswa. Materi pelajaran yang sudah terprogram disajikan secara serempak dengan menggabungkan komponen gambar, tulisan, warna, dan suara.

Posisi media pembelajaran sebagai sumber belajar akan mulai menggeser fungsi guru terutama sebagai sumber belajar. Salah satu media yang dapat menjalankan fungsi demikian tersebut adalah program multimedia interaktif sebagai media pembelajaran. Menurut Munadi (2008, pp.152-153) keunggulan program multimedia interaktif, di antaranya yaitu Interaktif, Saat siswa mengaplikasikan program ini, ia diajak untuk terlibat secara auditif, visual, dan kinetik, sehingga dengan pelibatan ini dimungkinkan informasi atau pesannya mudah dimengerti, Memberikan iklim afeksi secara individual, Meningkatkan motivasi belajar, Memberikan umpan balik, dan Kontrol pemanfaatannya sepenuhnya berada pada penggunanya.

Di samping keunggulan-keunggulan di atas, Munadi (2008, p.153) juga menyebutkan kelemahan multimedia interaktif, yaitu pengembangannya memerlukan adanya tim yang professional dan memerlukan waktu yang lama.

Roblyer \& Doering (2003, p.165) menyebutkan empat keunggulan multimedia dalam pembelajaran di kelas, yaitu motivation, flexibility, Development of creative and critical thinking skills, dan Improved writing and process skills. Penggunaan multimedia pembelajaran di kelas akan meningkatkan motivasi, fleksibilitas, mengembangkan kemampuan berpikir kritis dan kreatif, dan meningkatkan kemampuan memproses dan menulis. Siswa yang memamfaatkan multimedia dalam pembelajaran diharapkan dapat mencapai kompetensi hasil belajarnya secara optimal. Secara umum, Sadiman, et al. (2006, pp.17-18) menyatakan media sebagai alat bantu pembelajaran yang digunakan guru untuk, (1) memperjelas informasi/pesan pembelajaran, (2) mengatasi keterbatasan ruang, waktu, dan daya indera, (3) menimbulkan kegairahan belajar, (4) Memberi variasi belajar.

Selain efektifitasnya dalam hal komunikasi, beberapa keunggulan komputer sebagai media penyampai pesan dalam pembelajaran dijelaskan oleh Siahaan (Ismaniati, 2010, pp. 910) sebagai berikut: (1) membuat konkrit konsep yang abstrak, misalnya untuk menjelaskan sistem peredaran darah; (2) membawa objek yang berbahaya atau sukar didapat ke dalam lingkungan belajar, seperti: binatang-binatang buas, atau penguin dari kutub selatan; (3) menampilkan objek yang terlalu besar, seperti pasar, candi borobudur; menampilkan objek yang tidak dapat dilihat dengan mata telanjang, seperti: mikro organisme; (4) mengamati gerakan yang terlalu cepat, misalnya dengan slow motion atau timelapse photography; (5) memungkinkan siswa berinteraksi langsung dengan lingkungannya; (6) memungkinkan keseragaman pengamatan dan persepsi bagi pengalaman belajar siswa; (7) membangkitkan motivasi belajar siswa; (8) menyajikan informasi belajar secara konsisten, akurat, berkualitas dan dapat diulang penggunaannya atau disimpan sesuai dengan kebutuhan; (9) menyajikan pesan belajar secara serempak untuk lingkup sasaran yang sedikit/kecil atau banyak/luas, mengatasi batasan waktu (kapan saja) maupun ruang di mana saja).

Dari beberapa pendapat mengenai peran dan manfaat multimedia tersebut dapat disimpulkan manfaat praktis dari penggunaan multimedia pembelajaran di dalam proses pembelajaran yaitu (1) multimedia dalam pembelajaran dapat memberikan nuansa baru dan memperjelas penyajian pesan dan informasi sehingga dapat memperlancar dan meningkatkan proses dan hasil belajar karena sifatnya yang interaktif, efektif dan menyenangkan, (2) multimedia dalam pembelajaran dapat meningkatkan perhatian anak sehingga dapat menimbulkan motivasi belajar, interaksi yang lebih langsung antara siswa dan lingkungannya, dan memungkinkan siswa untuk belajar sendiri-sendiri sesuai dengan kemampuan dan minatnya, serta (3) media pembelajaran dapat mengatasi keterbatasan indera, ruang, dan waktu. Multimedia juga dapat digunakan untuk melakukan pembelajaran mandiri 


\section{Jurnal Riset Pendidikan Matematika, 3 (1), Mei 2016 - 93}

Nanang Khuzaini, Rusgianto Heri Santosa

maupun kelompok tergantung permasalahan yang harus diselesaikan.

\section{Pengembangan Multimedia Pembelajaran Interaktif}

Pengembangan media pembelajaran merupakan salah satu bidang garapan yang berupaya membantu proses belajar manusia dengan jalan memanfaatkan secara optimal komponenkomponen pembelajaran melalui fungsi pengembangan dan pengelolaan (Mukminan, 2012, p.5). Seels \& Richey (1994, p.9) menyatakan bahwa teknologi pembelajaran mempunyai empat kawasan yang saling terkait, yaitu: (1) the theory and practice; (2) design, development, utilization, management and evaluation; (3) processed and resources; and (4) learning.

Pengembangan multimedia termasuk dalam domain "pengembangan". Domain "pengembangan" termasuk kawasan kedua yaitu "design, development, utilization, management and evaluation". Menurut Daniamiseno (2011, p.4) manfaat teknologi pembelajaran adalah meningkatkan hasil atau keluaran pendidikan, membuat pembelajaran bersifat individual, pengembangan pembelajaran menjadi lebih ilmiah, berdaya mampu tinggi, aktual, seimbang, dan merata.

Lee \& Owen (2004, p.162) mengemukakan "whatever the type of multimedia, the basic development principles remain the same is establish a framework of development tools, development specifications, and standard, develop the media elements that fit into the framework, Then reviewed and revise the product, and finally, implement the finished product

\section{Model Pengembangan Multimedia Pembelajaran Interaktif menurut Borg dan Gall}

Model pengembangan Borg dan Gall (Hadi \& Suryono, 2014, p.264) terdiri atas 10 langkah pengembangan yang meliputi: (1) Research and information collecting atau penelitian dan pengumpulan informasi, yaitu meliputi kajian pustaka, pengamatan kelas, dan persiapan laporan tentang pokok permasalah-an, (2) Planning atau perencanaan, yaitu meliputi pendefinisian, perumusan tujuan, penentuan urutan pembelajaran, dan uji coba skala kecil, (3) Develop preliminary form of product atau mengembangkan bentuk produk awal, yaitu meliputi penyiapan materi pembelajaran, buku pegangan, dan perlengkap-an evaluasi, (4) Preliminary field testing atau melakukan uji coba lapangan awal, yaitu pengumpulan data awal dengan wawancara, pengamatan dan angket dan dilakukan analisis, (5) Main product revision atau revisi produk, yaitu melakukan revisi produk sesuai dengan saran-saran pada uji coba lapangan awal, (6) Main field testing atau melakukan uji coba utama, yaitu dilakukan uji coba yang bertujuan untuk mendapatkan data kuantitatif, (7) Operational product revision atau revisi produk operasional, yaitu melakukan revisi produk sesuai dengan yang disarankan pada hasil uji coba lapangan utama, (8) Operational field testing atau melakukan uji coba lapangan operasional, yaitu uji coba produk dan dilakukan pengumpulan data dengan wawancara, pengamatan, dan angket, dan dianalisis (9) Final product revision atau revisi produk akhir sesuai yang disarankan pada uji coba lapangan operasional, (10) Dissemination and implementation atau diseminasi dan implementasi dengan membuat laporan mengenai produk dalam pertemuan profesional dan jurnal.

\section{Kualitas Produk Multimedia Pembelajaran Interaktif}

Treffers (Cobb, Gravemeijer, \& Yackel, 2011, p.77) menyatakan bahwa "the purpose for conducting design experiments was not limited to developing explanatory constructs, but could also include developing, testing, and revising sequences of instructional activities". Dapat diartikan bahwa tujuan dari sebuah desain penelitian tidak hanya untuk membangun sebuah konstruk yang jelas, tetapi juga mencakup pengembangan, pengujian, dan memperbaiki aktivitas pengajaran.

Richey (2008, p.732) menyatakan bahwa "...products that must meet the criteria of internal consistency and effectiveness". Hal ini menunjukkan produk yang dihasilkan dalam penelitian pengembangan harus memenuhi kriteria konsistensi internal, dan efektifitas. Untuk memenuhi kriteria pembelajaran dan kualitas produk yang meliputi pendesainan, pengembangan, dan pengevaluasian program yang baik, menurut Nieveen $(1999$, p.127) harus memenuhi kriteria valid, praktis, dan efektif. Untuk tiga kriteria tersebut dapat dilihat pada Tabel 1. 
Jurnal Riset Pendidikan Matematika, 3 (1), Mei 2016 - 94

Nanang Khuzaini, Rusgianto Heri Santosa

Tabel 1. Kriteria Kualitas Aspek Multimedia

\begin{tabular}{llll}
\hline & \multicolumn{1}{c}{ Validity } & \multicolumn{1}{c}{ Quality Aspects } & \multicolumn{1}{c}{ Practically } \\
\cline { 2 - 4 } Representations & Intended (ideal+formal) & Consistensy between & Consistensy between \\
& $\bullet$ State-of-the-art & $\bullet$ Intended Perceived & $\bullet$ Intended Experiential \\
& $\bullet$ Internally consistent & $\bullet$ Intended Operational & $\bullet$ Intended Attained \\
\hline
\end{tabular}

METODE

\section{Jenis dan Desain Penelitian}

Penelitian ini merupakan jenis penelitian pengembangan, yaitu suatu proses penelitian yang digunakan untuk mengembangkan suatu produk. Desain penelitian pada penelitian ini dititikberatkan pada pengembangan produk multimedia pembelajaran matematika pada materi trigonometri. Adapun langkah-langkah desain penelitian yang dilakukan adalah: Pertama, Pendahuluan yang meliputi (1) Studi pustaka, yaitu mengkaji teori-teori dan hasil penelitian yang relevan sesuai dengan penelitian dan pengembangan yang akan dilakukan dan (2) Menganalisis kebutuhan siswa terhadap multimedia pembelajaran matematika.

Tahap analisis kebutuhan adalah tahap awal dimana dilakukan pengumpulan berbagai informasi yang akan berhubungan dengan produk yang akan dikembangkan guna mengatasi masalah yang ditemui dalam kegiatan pembelajaran, khususnya kegiatan pembelajaran matematika. Pada tahap ini dilakukan dengan mengumpulkan nilai ulangan matematika pada semester genap tahun ajaran 2011/2012. Selain itu dilakukan juga wawancara terhadap guru terkait dengan kegiatan pembelajaran matematika yang berlangsung selama ini.

Kedua, pengembangan yang meliputi, (1) menentukan standar kompetensi, kompetensi dasar, indikator dan materi pokok yang akan disajikan. Dari hasil penelitian tahap pendahuluan telah ditetapkan bahwa standar kompetensi yang akan digunakan dalam penelitian adalah menggunakan perbandingan, fungsi, persamaan, dan identitas terigonometri dalam pemecahan masalah, (2) menganalisis multimedia pembelajaran matematika tentang materi trigonometri yang mungkin telah dikembangkan. Dari hasil penelitian tahap pendahuluan belum ditemukan multimedia pembelajaran matematika materi pokok yang dikembangkan menggunakan Adobe Flash CS3. Oleh karena itu perlu dikembangkan multimedia pembelajaran matematika terkait materi tersebut, (3) menyusun multimedia pembelajaran matematika tentang materi trigonometri, (4) menyusun instrumen penelitian yang meliputi: angket untuk ahli dan angket siswa (berupa angket kualitas teknis). Dalam penilaian kualitas produk ditinjau dari tiga hal, yaitu kevalidan, keefektifan dan kepraktisan produk. Oleh karena itu disusun instrumen penelitian berupa angket penilaian multimedia pembelajaran matematika, (5) menyusun instrumen tes berupa soal ulangan untuk menilai pencapaian ketuntasan belajar siswa. Untuk menilai keefektifan produk salah satunya ditinjau dari prestasi belajar siswa. Oleh karena itu disusun instrume tes berupa soal ulangan matematika untuk melihat keefektifan multimedia pembelajaran matematika.

Ketiga adalah validasi, Produk multimedia yang telah dihasilkan sebelum dimanfaatkan secara umum dilakukan validasi terlebih dahulu dengan cara diujicobakan. Uji coba produk dimaksudkan untuk memperoleh masukan-masukan maupun koreksi kualitas multimedia pembelajaran yang dikembang-kan dalam rangka untuk mencapai suatu tujuan pembelajaran matematika, baik dari aspek pembelajaran, materi, maupun media. Untuk memperoleh produk multimedia pembelajaran yang baik, diperlukan serangkaian validasi. Desain validasi dalam penelitian ini adalah sebagai berikut: (1) uji pengembangan terbatas dan review ahli materi dan ahli media, uji pengembangan terbatas ini dilaksanakan untuk mendapatkan kevalidan produk yang dilihat dari aspek materi, pembelajaran, dan media, (2) uji coba kelompok kecil, dalam tahap ini uji coba dilakukan terhadap 12 siswa SMA kelas X. Pemilihan siswa dilakukan secara random dengan memperhatikan perbedaan kemampuan siswa (empat siswa berkemampuan rendah, empat siswa berkemampuan sedang, dan empat siswa berkemampuan tinggi). Hasil yang diharapkan dari uji coba ini adalah desain produk yang praktis dari sisi penggunaan. Data yang diberikan siswa melalui angket, kritik, dan saran digunakan sebagai dasar perbaikan multimedia, (3) uji coba lapangan dan kelayakan, dalam tahap ini, uji coba dilakukan terhadap seluruh siswa kelas X SMA UII Yogyakarta yang berjumlah 90 siswa yang terbagi dalam 3 kelas. Pada saat melaksanakan uji coba lapangan dan kelayakan, pengajar yang bertugas 
sebagai guru adalah peneliti sendiri. Uji coba lapangan dimaksudkan untuk menilai keefektifan dan kepraktisan suatu produk yang dikembangkan. Data yang diberikan siswa melalui angket, kritik, dan saran digunakan sebagai dasar perbaikan multimedia.

\section{Teknik Analisis Data}

Data yang diperoleh dari para ahli dan praktisi dianalisis untuk menentukan kevalidan multimedia pembelajaran matematika ditinjau dari segi teoritis dan konsistensi di antara komponen-komponen multimedia pembelajaran, sedangkan data hasil uji coba di lapangan digunakan untuk menjawab kriteria kepraktisan dan keefektifan perangkat pembelajaran yang dikembangkan.

Langkah-langkah yang digunakan untuk memberikan kriteria kualitas terhadap produk yang dikembangkan adalah sebagai berikut : (1) Data yang berupa skor penilaian ahli, guru, dan siswa yang diperoleh dalam bentuk kategori yang terdiri atas lima pilihan penilaian tentang kualitas produk perangkat pembelajaran yang dikembangkan, yaitu sangat baik (5), baik (4), cukup (3), kurang (2), sangat kurang (1) dirubah menjadi data interval, (2) Setelah dirubah menjadi data interval, skor yang diperoleh kemudian dikonversi-kan menjadi data kualitatif skala lima, dengan acuan rumus yang dikutip dari acuan rumus yang diadaptasi dari Azwar (2013: 163). Skala lima tersebut digunakan untuk menganalisis data yang merupakan penilaian terhadap multimedia pembelajaran matematika, dan tingkat motivasi belajar siswa sebelum dan sesudah menggunakan multimedia pembelajaran matematika yang dikembangkan.

\section{Teknik Analisis Data Kevalidan}

Data berupa skor penilaian validator yang diperoleh dalam bentuk kategori yang terdiri atas lima pilihan penilaian tentang kualitas produk multimedia pembelajaran matematika yang dikembangkan, yaitu sangat baik (5), baik (4), cukup (3), kurang (2) dan sangat kurang (1). Data tersebut dirubah menjadi data interval.

Banyak item validasi untuk ahli materi dan pembelajaran adalah 14 item (skor minimum ideal $=14$, skor maksimum ideal $=70, \bar{x}_{\mathrm{i}}=$ 42 dan SBi = 9,33), dan banyak item validasi untuk ahli media adalah 10 item (skor minimum ideal $=10$, skor maksimum ideal $=50, \bar{x}_{l}=30$ dan SBi $=6,67)$, sehingga diperoleh kriteria interval untuk menentukan kategori validitas masing-masing untuk kriteria pendidikan dan tampilan program, seperti pada pada Tabel 2:

Tabel 2. Kriteria Interval Kevalidan Multimedia

\begin{tabular}{|c|c|c|c|}
\hline \multicolumn{2}{|l|}{ Interval } & \multirow[b]{2}{*}{ Nilai } & \multirow[b]{2}{*}{ Kategori } \\
\hline $\begin{array}{c}\text { Kriteria Materi dan } \\
\text { Pembelajaran }\end{array}$ & $\begin{array}{l}\text { Kriteria } \\
\text { Media }\end{array}$ & & \\
\hline$X>58,8$ & $X>42$ & $\mathrm{~A}$ & Sangat baik \\
\hline $49,47<X \leq 58,8$ & $\begin{array}{c}34<\mathrm{X} \leq \\
42\end{array}$ & B & Baik \\
\hline $34,53<X \leq 49,47$ & $\begin{array}{c}26<X \leq \\
34\end{array}$ & $\mathrm{C}$ & Cukup \\
\hline $25,2<X \leq 34,53$ & $\begin{array}{c}18<X \leq \\
26\end{array}$ & $\mathrm{D}$ & Kurang \\
\hline$X \leq 25,2$ & $X \leq 18$ & $\mathrm{E}$ & $\begin{array}{l}\text { Sangat } \\
\text { Kurang }\end{array}$ \\
\hline
\end{tabular}

Multimedia pembelajaran matematika yang dihasilkan dikatakan baik jika minimal tingkat kualitas untuk masing-masing kriteria yang dicapai adalah kategori baik.

\section{Teknik Analisis Data Kepraktisan}

Data kepraktisan multimedia pembelajaran matematika diperoleh dari penilaian guru dan siswa terhadap multimedia pembelajaran matematika. Kepraktisan multimedia pembelajaran matematika yang dikembangkan diukur berdasarkan hasil penilaian dari guru dan siswa yang menggunakan produk pada saat uji coba. Skor penilaian yang diperoleh dari guru dan siswa dikonversi menjadi data kualitatif skala lima.

Banyak item untuk penilaian siswa adalah 10 item dan penilaian dilakukan oleh 90 orang siswa (skor maksimum ideal $=450$, skor minimum ideal $=90, \overline{x_{l}}=270$ dan SBi $=60$ ). Banyak item untuk penilaian guru adalah 10 item dan penilaian dilakukan oleh guru (skor maksimum ideal $=10$, skor minimum ideal $=2$, $\overline{x_{l}}=6$ dan $\mathrm{SBi}=1,3$ ), sehingga diperoleh kriteria interval kepraktisan menurut penilaian siswa dan guru seperti pada Tabel 3:

Tabel 3. Kriteria Interval Kepraktisan

\begin{tabular}{cccc}
\hline \multicolumn{2}{c}{ Interval } & & \\
\cline { 1 - 2 } $\begin{array}{c}\text { Penilaian } \\
\text { Siswa }\end{array}$ & $\begin{array}{c}\text { Penilaian } \\
\text { Guru }\end{array}$ & Nilai & Kategori \\
\cline { 1 - 2 } $\mathrm{X}>378$ & $\mathrm{X}>8,4$ & $\mathrm{~A}$ & Sangat baik \\
$306<\mathrm{X} \leq 378$ & $6,8<\mathrm{X} \leq 8,4$ & $\mathrm{~B}$ & Baik \\
$234<\mathrm{X} \leq 306$ & $5,2<\mathrm{X} \leq 6,8$ & $\mathrm{C}$ & Cukup baik \\
$162<\mathrm{X} \leq 234$ & $3,6<\mathrm{X} \leq 5,2$ & $\mathrm{D}$ & Kurang baik \\
$\mathrm{X} \leq 162$ & $\mathrm{X} \leq 3,6$ & $\mathrm{E}$ & Tidak baik \\
\hline
\end{tabular}

Multimedia pembelajaran matematika yang dikembangkan dikatakan praktis jika penilaian kepraktisan perangkat pembelajaran oleh guru dan siswa konsisten minimal berada pada kategori baik. Penilaian guru dan siswa dapat 


\section{Jurnal Riset Pendidikan Matematika, 3 (1), Mei 2016 - 96}

Nanang Khuzaini, Rusgianto Heri Santosa

dilihat pada Lampiran C. Jumlah butir pernyataan penilaian kepraktisan untuk guru dan siswa berjumlah sama yaitu 10 butir.

\section{Teknik Analisis Data Keefektifan}

Analisis terhadap keefektifan multimedia pembelajaran matematika dilakukan terhadap data hasil tes prestasi belajar yang diperoleh oleh siswa. Langkah-langkah dalam analisis data tes hasil belajar adalah sebagai berikut: (1) menghitung skor tiap siswa, (2) menghitung frekuensi siswa yang mencapai tingkat hasil belajar yang ditentukan, atau Kriteria Ketuntasan Minimal (KKM) yang telah ditetapkan, yaitu 75 dari skor maksimal yaitu 100 .

Menentukan ketercapaian hasil belajar untuk seluruh siswa dan menyimpulkan berdasarkan kriteria yang telah ditetapkan yaitu jika $80 \%$ dari $100 \%$ siswa mencapai skor 75 dari skor maksimal yaitu 100, maka multimedia pembelajaran matematika dapat dikatakan efektif.

\section{HASIL}

\section{Tahap Pendahuluan}

Tahap yang sudah dilakukan dalam pendahuluan ini adalah sebagai beikut: (1) menganalisis standar kompetensi menggunakan perbandingan, fungsi, persamaan, dan identitas trigonometri dalam pemecahan masalah untuk disampaikan melalui multimedia pembelajaran. Proses ini meliputi kajian materi matematika yang sesuai dengan standar isi, (2) mengumpulkan referensi mengenai materi pokok trigonometri. Pemilihan standar kompetensi perbandingan, fungsi, persamaan, dan identitas trigonometri dalam pemecahan masalah karena pada standar kompetensi tersebut hasil belajar siswa masih banyak yang masih di bawah KKM (hasil pra survei yang dilakukan di SMA UII Yogyakarta). Selain itu, nilai ujian nasional (UN) di SMA UII Yogyakarta pada standar kompetensi tersebut selama tiga tahun terakhir mengalami penurunan, (3) merencanakan dan memilih jenis media pembelajaran yang akan digunakan. Multimedia pembelajaran yang dipilih yaitu berupa CD pembelajaran yang dapat digunakan dengan perangkat komputer. Pemilihan ini dikarenakan pengemasan dalam bentuk CD sangat efektif karena mempunyai memori yang cukup besar dan tidak mudah terhapus, selain itu multimedia pembelajaran ini dibuat menggunakan program Adobe Flash CS3 yang penggunaannya harus menggunakan komputer.

\section{Tahap Pengembangan}

Pembuatan multimedia pembelajaran ini membahas tentang standar kompetensi menggunakan perbandingan, fungsi, persamaan, dan identitas trigonometri dalam pemecahan masalah. Standar kompetensi tersebut memuat 3 kompetensi dasar, yaitu (1) melakukan manipulasi aljabar dalam perhitungan teknis yang berkaitan dengan perbandingan, fungsi, persamaan dan identitas trigonometri, (2) merancang model matematika dari masalah yang berkaitan dengan perbandingan, fungsi, persamaan dan identitas trigonometri, dan (3) menyelesaikan model matematika dari masalah yang berkaitan dengan perbandingan, fungsi, persamaan dan identitas trigonometri dan penafsirannya.

Tahap ini merupakan desain awal pembuatan multimedia pembelajaran matematika yang dikembangkan. Desain tersebut menggambarkan alur halaman yang tersedia pada multimedia mulai dari halaman pembuka hingga halaman penutup.

\section{Validasi}

Melakukan validasi multimedia pembelajaran yang telah direvisi kepada ahli materi dan pembelajaran, ahli media, dan siswa (kelas besar dan kelas kecil) disertai instrumen penilaian kesesuaian media pembelajaran. Multimedia pembelajaran divalidasi terlebih dahulu oleh ahli materi dan pembelajaran, dan ahli media. Setelah mendapat masukan dari ahli materi dan pembelajaran serta ahli media kemudian multimedia pembelajaran direvisi untuk medapatkan revisi I. Setelah multimedia pembelajaran dinyatakan sudah layak untuk digunakan kemudian multimedia pembelajaran diujicobakan kepada kelas kecil. Setelah mendapat masukan dari siswa pada kelas kecil kemudian multimedia pembelajaran direvisi untuk mendapatkan revisi II. Setelah mendapatkan revisi II kemudian multimedia pembelajaran diujicobakan kepada kelas besar. Setelah diujicobakan dan mendapatkan masukan dari siswa pada kelas besar kemudian multimedia di revisi untuk mendapatkan revisi III.

\section{Data Uji Coba}

Data hasil uji coba pengembangan terbatas dilihat data kevalidan berdasarkan penilaian ahli materi dan pembelajaran terhadap multimedia pembelajaran matematika. Ahli Materi terdiri atas 3 orang memberikan penilaian terhadap kevalidan multimedia pembelajaran mate- 
matika. Hasil penilaian kevalidan ini digunakan sebagai prasyarat dilaksanakannya uji kelas kecil yang akan dilaksanakan disekolah. Data adalah hasil penilaian dari ahli materi terhadap multimedia pembelajaran matematika untuk siswa SMA pada standar kompetensi menggunakan perbandingan, fungsi, persamaan, dan identitas trigonometri dalam pemecahan masalah yang sudah dihasilkan.

Begitu juga dengan Ahli Pembelajaran dalam pengembangan media pembelajaran ini, terdiri atas 3 orang yang memberikan penilaian terhadap kevalidan multimedia pembelajaran matematika yang sudah dihasilkan. Hasil penilaian skor kevalidan ini digunakan sebagai prasyarat dilaksanakannya uji kelas kecil. Data yang diperoleh dari penilaian ahli materi dan pembelajaran terhadap multimedia pembelajaran matematika untuk siswa SMA adalah 58,6. Sedangkan data skor penilaian ahli media terhadap multimedia pembelajaran matematika untuk siswa SMA adalah 39,5. Data kepraktisan dapat dilihat dari penilaian siswa, penilaina siswa pada kelompok kecil dengan jumlah siswa 12 orang adalah sangat baik sebesar $30 \%$, baik sebesar $45 \%$, cukup sebesar $18,3 \%$, kurang sebesar $6,7 \%$, dan sangat kurang sebesar 0\%. Sedangkan untuk data uji coba kelas besar dengan jumlah siswa 90 orang adalah sangat baik sebesar $34,9 \%$, baik sebesar 42,3\%, cukup sebesar $18,3 \%$, kurang sebesar $4,5 \%$, dan sangat kurang sebesar $0 \%$. Keefektifan multimedia dapat dilihat dari hasil tes dan ketuntasan KKM siswa, Untuk mendapatkan data persentase pencapaian kriteria ketuntasan minimal yaitu dilaksanakannya tes pada akhir pembelajaran yang menggunakan tes hasil belajar. Data yang diperoleh adalah siswa kelas XA dengan rata-rata nilai sebesar 79,2, dari 29 siswa yang mengikuti tes 25 siswa sudah mencapai KKM; siswa kelas XB dengan rata-rata nilai sebesar 76,8, dari 31 siswa yang mengikuti tes 24 siswa sudah mencapai $\mathrm{KKM}$; siswa kelas XC dengan rata-rata nilai sebesar 78,2, dari 30 siswa yang mengikuti tes 24 siswa sudah mencapai KKM. Rekap data dari semua siswa yang mengikuti tes sebanyak 90 siswa dari 3 kelas adalah 73 siswa atau sebesar $81,11 \%$ sudah mencapai KKM yang sudah ditetapkan.

\section{SIMPULAN DAN SARAN}

\section{Simpulan}

Berdasarkan hasil penelitian dan pembahasan diperoleh simpulan sebagai berikut:
Produk yang dikembangkan berupa multimedia pembelajaran matematika tentang materi trigonometri. Multimedia pembelajaran matematika memuat 7 sub bab yaitu tokoh matematika, perbandingan trigonometri, perbandingan trigonometri untuk sudut khusus, perbandingan trigonometri untuk sudut-sudut di semua kuadran, sudut berelasi, koordinat kutub dan koordinat kartesius, fungsi trigonometri, grafik fungsi trigonometri. Selain itu multimedia pembelajaran matematika juga menyediakan latihan-latihan soal yang interaktif yang memudahkan siswa mempelajari materi trigonometri. Produk ini telah diujicobakan di SMA UII Yogyakarta sehingga layak digunakan dalam kegiatan pembelajaran dengan skala yang lebih luas. Hasil pengembangan yang berupa multimedia pembelajaran matematika dinyatakan valid berdasarkan penilaian ahli materi dan pembelajaran, dan ahli media. Penilaian ahli-ahli tersebut secara konsisten mengkategorikan multimedia pembelajaran matematika dalam kategori valid. Ahli media secara konsisten memberikan skor 39,5 dan ahli meteri dan pembelajaran secara konsisten memberikan skor 58,6. Hasil pengembangan yang berupa multimedia pembelajaran matematika dinyatakan praktis berdasarkan penilaian siswa. Penilaian siswa secara konsisten mengkategorikan multimedia pembelajaran matematika dalam kategori praktis dengan memberikan skor sebesar 369,3. Hasil pengembangan yang berupa multimedia pembelajaran matematika dinyatakan efektif berdasarkan hasil tes prestasi belajar siswa. Dari hasil tes prestasi belajar secara konsisten menyatakan bahwa multimedia pembelajaran matematika dapat meningkatkan prestasi belajar matematika siswa, $81,11 \%$ siswa sudah mencapai KKM.

\section{Saran}

Berdasarkan simpulan yang dikemukakan di atas, maka beberapa saran yang perlu dipertimbangkan untuk peningkatan kualitas pembelajaran matematika sekolah sebagai berikut: (1) Multimedia pembelajaran matematika pada materi trigonometri yang telah dihasilkan telah teruji kelayakannya, yaitu telah memenuhi kriteria valid, praktis dan efektif, sehingga valid dan layak digunakan dan dapat dimanfaatkan untuk pembelajaran di sekolah-sekolah yang memiliki fasilitas laboratorium computer, (2) Produk yang dikembangkan ini dapat dijadikan sebagai contoh multimedia pembelajaran yang interaktif yang dapat disebarluaskan serta menjadi bahan masukan para guru dalam kegiatan 
pembelajaran matematika yang memanfaatkan multimedia pembelajaran matematika, (3) Pengembangan multimedia pembelajaran matematika hanya dilakukan untuk materi trigonometri, maka disarankan untuk peneliti lain untuk mengembangkan multimedia pembelajaran matematika untuk materi lainnya.

\section{DAFTAR PUSTAKA}

Agnew, P.W., Kellerman, A.S \& Meyer, M.J. (1996). Multimedia in the classroom. Boston: Allyn and Bacon.

Alessi, S.M., \& Trollip, S.R. (2001). Multimedia for learning method and development. Needham Heights: Allyn \& Bacon.

Arsyad, A. (2006). Media pembelajaran. Jakarta: Raja Grafindo.

Ayda, E., \& Widjajanti, D. (2014). Pengembangan perangkat pembelajaran teorema pythagoras dengan media berbantuan komputer. Jurnal Riset Pendidikan Matematika, 1(2), 216-226. doi:http://dx.doi.org/10.21831/jrpm.v1i2. 2677

Borovcnik, M., \& Kapadia, R. (2009). Research developments in probability education. International electronik journal of mathematics education, 4, 11-130.

BSNP. (2007). Peraturan menteri pendidikan nomor 41 tahun 2007 tentang standar proses. Jakarta: Depdiknas.

Cobb, P., Gravemeijer, K., \& Yackel, E. (2011). Symbolizing And instructtional designdeveloping instructional sequen-ces to support students mathematical learning. Dalam Sfard. A., Gravemeijer, K., \& Yackel, E. (Eds.), A Journey in mathematics education research (pp. 7682). New York : Springer.

Damniamiseno, A.G. (2011). Pemanfaatan teknologi informasi dan komunikasi (ICT) dalam pengembangan pem-belajaran. Makalah disampaikan dalam Seminar Pendidikan di FKIP Universitas Sanat Dharma Yogyakarta pada tanggal 15 Januari 2011.

Gyongyver, M. (2001). New ICT in educationclasroom of the future project. disampaikan dalam Framework of The Research Group on The Development of
Competence University of Szeged, Hungaria.

Hackbarth, S. (1996). The Educational technology handbook: comprehensive guide process and products for learning. New Jersey: Educ. Tech-nology Publ.

Hadi, S., \& Suryono, Y. (2014). Pengembangan model evaluasi pendidikan kecakapan hidup pada pendidikan luar sekolah. Jurnal Penelitian dan Evaluasi Pendidikan, 18(2), 261-274. doi:http://dx.doi.org/10.21831/pep.v18i2. 2865

Ismaniati, CH. (2010). Penggunaan teknologi informasi dan komunikasi dalam peningkatan kualitas pembelajaran. Yogyakarta: Universitas Negeri Yogyakarta.

Kemp, E.J., \& Dayton. (1985). Planing and producing instructional media. New York: harper \& Row Publisher Inc.

Lee, W.W., \& Owen, D.L. (2004). Multimediabased instructional design. San Francisco, CA : John Wiley \& Sons, Inc

Muijs, D. \& Reynalds, D. (2005). Effective teaching: Evidence and practice (2nd ed). London: SAGE.

Mukminan. (2012). Teknologi pem-belajaran dan peran ict dalam rangka redesain pembelajaran menyongsong pendidikan di era global. Disampaikan Pada Seminar Pendidikan Dengan Tema "Redesain Pem-belajaran Menyongsong Pendidikan di Era Global" di Universitas Jambi pada tanggal 21 April 2012.

Mulyasa. (2013). Menjadi guru profesional menciptakan pembelajaran kreatif dan menyenangkan. Bandung: Remaja Rosda Karya

Munadi, Y.(2008). Media pembelajaran; sebuah pendekatan baru. Jakarta: Gaung Persada Pers.

Newby, T., Stepich, D., Lehman, J. \& Russell, J. (1996). Instructional technology for teaching and learning: designing instruction, integrating computers, and using media. Columbus: Merill.

Nieveen, N., et al. (1999). Prototyping to reach product quality. London: Kluwer Academic Publisher. 


\section{Jurnal Riset Pendidikan Matematika, 3 (1), Mei 2016 - 99}

Nanang Khuzaini, Rusgianto Heri Santosa

Richey, R. C., Klein, J. D., \& Nelson, W. A. (2003). Design research. Dalam Jonassen, D. H. (Eds.), Handbook of research for educational communi-cations and technology (3 ed.), (pp. 715-734). Princeton, NJ: Lawrence Erlbaum Associates.

Roblyer, M.D., \& Doering, A.H. (2003). Integrating educational technology into teaching. Mahwah, NJ: Pearson Education, Inc.

Roblyer, M.D., \& Doering, A.H. (2003). Integrating educational technology into teaching. Mahwah, NJ: Pearson Education, Inc.

Sadiman, A.S. et al. (2006). Media Pendidikan: Pengertian, pengembangan, dan pemanfaatan, Jakarta: Pustekkom Diknas \& Raja Grafindo Perkasa.

Seels, B. B. \& Richey, R. C. (1994). Instructional technology: the definition and domain of the field. Woshington, DC: Aect.

Sousa, D. A. (2008). How the brain learns mathematics. Thousand Oaks, CA: Corwin Press.

Trianto. (2009). Mendesain model pembelajaran inovatif-progresif: konsep, landasan, dan implementasinya pada kurikulum tingkat satuan pendidikan (KTSP). Jakarta: Kencana.

Van den Heuvel-Panhuizen, M (2000). Mathematics education in the Netherlands: A guide tour. CD-Rom of the RME Materials, produced for the ICME9 Congress in Japan, July 2000.

Vaughan, T. (2006). Multimedia making it work. (terjemahan Theresia Arie Prabawati \& Agnes Heni Triyuliana. Yogyakarta: ANDI. 